\title{
BOARD OF DIRECTORS: THE PERSPECTIVE OF INDEPENDENTS IN THE PERFORMANCE OF PRIVATE ORGANIZATIONS? EVIDENCES IN BRAZIL
}

\author{
RUAN C. DOS SANTOS 1 \\ (iD) https://orcid.org/0000-0001-7396-8774 \\ LIDINEI É. ORSO \\ (iD) https://orcid.org/0000-0002-8128-4337 \\ SUZETE A. LIZOTE \\ (iD) https://orcid.org/0000-0003-3575-1675 \\ ROSILENE MARCON ${ }^{2}$ \\ (iD) https://orcid.org/0000-0002-0478-7715
}

To cite this paper: Santos, R. C. dos, Orso, L. É., Lizote, S. A., \& Marcon, R. (2018). Board of directors: The perspective of independents in the performance of private organizations? Evidences in Brazil. Revista de Administração Mackenzie, 19(4). doi:10.1590/1678-6971/eRAMF180003

Submission: Jan. 11, 2018. Acceptance: Jun. 7, 2018.

1 Centro Universitário Leonardo Da Vinci (Uniasselvi), Tijucas, SC, Brasil.

2 Universidade do Vale do Itajaí (Univali), Biguaçu, SC, Brasil.

\section{(cc) BY}




\section{ABSTRACT}

Purpose: The study seeks to verify the influence of the board of directors' independence on the performance of BM\&FBOVESPA listed companies and to analyse which agency conflicts influence the performance of the board of directors.

Originality/value: The factor of Brazil being an emerging country which lacks a strict legal system and control factors against corruption in these environments and the public sectors emphasizes the importance of applying the best corporate governance practice code in the main developed countries, reflecting the need for effective supervisory bodies that contribute to better financial performance of companies.

Design/methodology/approach: The study involved a quantitative survey using a sample of 33 companies in the highway operating segment and 220 reports from 2010 to 2016. A fixed-effects regression model with panel data was used for analysis.

Findings: The results were statistically significant for the board's independence variables, which confirm the theory that the presence of independents as members of the board positively influences financial management and the company that holds the executive member and chairman of the board positions has a negative effect. The size of the board did not present statistical significance.

\section{KEYWORDS}

Agency theory. Corporate governance. Board of administration. Independent advisor. Performance. 


\section{INTRODUCTION}

The government's policy decisions regarding its provision and development of the infrastructure, logistics and transportation sector have brought growth to the entire economy. The infrastructure of a nation is a critical issue for the operation and efficiency of modern economies. Infrastructure, particularly road transport, is an important element linked to the productivity, costs and competitiveness of a society (Guasch, 2004). According to Guasch (2004), road concessions arose from the need for investments to guarantee the construction, recovery, maintenance and improvement of infrastructure, as well as the search for efficiency and modernity in the provision of services essential to society.

The regulation of the Brazilian industry and the GDP (Gross Domestic Product) prove the effectiveness of private investment in public policies, with not only economic advantages, but also practices in which the individual is able to provide a more qualified public service. It is, therefore, increasingly important for society to approach the state of private initiative, directed towards the collection of private capital for investment and the financing of public works and services (Bittencourt, 2006). From the relationship involving the state and the economy, its projects, interests and problems, government regulation emerged. According to Posner (2007), two hypotheses may have characterized the thinking that allowed the idea of regulation of the economy: the first is that economic markets are fragile and will malfunction if left unattended; and second, state regulation is virtually free. This thinking is criticized by arguments that allow the formulation of economic regulation theory.

The interest that research has paid to boards of directors is not related to the attention it has awakened in the business world. The development of best corporate governance practice codes in the main developed countries reflects the need for effective supervisory bodies that contribute to better financial performance of companies. Virtually, all corporate governance codes emphasize the importance of a board of directors in which: 1 . there is a majority of independent members; 2 . the position of CEO and the chairman of the board of directors is occupied by different people; and 3. there is an adequate number of members and information properly disclosed.

The adoption of corporate governance mechanisms by companies allowed better control of risks in financial decision-making, which may increase or reduce the price of market shares and, consequently, affect their 
performance and market value (Adi, Handayani, \& Rahayu, 2013). As a result, corporate governance practices, coupled with an adequate capital structure, offer companies a more attractive market status, facilitating fundraising, reducing agency costs, reducing losses and increasing the performance and profitability of the company (Koerniadi, Krishnamurti, \& Tourani-Rad, 2014). One of the most important governance mechanisms is the board of directors, designed to monitor top management actions and the quality of information contained in financial reports (Siam, Laili, \& Khairi, 2014). For Chen, Cheng, and Wang (2015) and Shah, Zafar, and Durrani (2009), one of the key responsibilities of the board of directors is to ensure that shareholders and other stakeholders receive high-quality information about the financial and operating results of a company.

In this sense, corporate governance practices can effectively contribute to attenuate managers' opportunistic behaviour and improve the quality of information disclosed (Chen et al., 2015). Researchers such as Habbash, Xiao, Salama, and Dixon (2014) emphasize that corporate governance has its main focus on improving the quality of financial reporting and creating effective mechanisms for monitoring management.

An important factor that may affect the board's ability to monitor managers is its independence from the controlling shareholders and management. For this, it is necessary to appoint independent members to the positions of directors (Alves, 2014). In comparison with other members, independent directors are less susceptible to problems of self-interest and less subject to the influence of controllers and managers. So, independent advisors are more effective monitors compared to other advisors. Thus, an increase in board independence may increase the organization's performance (Chen et al., 2015).

In the international literature, the relationship between the independence of the board of directors and corporate performance is a topic presenting quite divergent results. While some researchers (Alves, 2014; Chen et al., 2015; Du, Jian, \& Lai, 2017) show that board independence contributes to a reduction in conflicts of interest, others (Habbash et al., 2014; Rajpal, 2012; Shah et al., 2009; Wu, Chen, \& Lee et al., 2016) demonstrate that there is no such influence.

In Brazil, the investigation of this topic also constitutes a relevant research gap, since the existing literature has analysed the influence of corporate governance practices in general, without specifically focusing on the independence of the board of directors. For example, Piccoli, Souza, and Silva (2014) investigated the association between corporate governance 
and performance, using as a proxy for governance the differentiated levels of the stock exchange (BM\&FBOVESPA), the guidelines and parameters of the Brazilian Corporate Governance Institute (Brazilian Institute of Corporate Governance [IBGC], 2012).

This research contributes to this gap found in the literature review. Based on the foregoing, the problem question that guides this study is: What is the influence of the board of directors' independence on the performance of companies? Thus, the general objective is to verify the influence of the board of directors' independence on the performance of listed companies in the highway exploration segment listed on the BM\&FBOVESPA.

The study is justified by divergences found in previous international research results of a similar nature to that under scrutiny. In addition, the research aims to strengthen the understanding around this theme in the Brazilian scenario, expanding the discussion by addressing an influential factor in performance (board independence) still little explored in Brazil. It also contributes to the literature with empirical evidence regarding the Brazilian scenario, still lacking in research of this nature.

The investigation is also justified by the importance of the issue in the face of the agency problem in companies. In a lot of research, the emphasis is on agency problems caused by the separation of ownership and management in large corporations. Jensen and Meckling (1976) formalized the agency problem in a study that describes agency theory, examining the relationships between principal and agent.

\section{LITERATURE REVISION}

\subsection{Agency theory and corporate governance}

Managing the quality of corporate governance at the enterprise level can help in the investigation of specific governance practices, such as board independence, CEO identity and executive compensation. However, in order to gain a broader view of the general practices of corporate governance, individual academic researchers have incorporated either single governance elements into their metrics or the overall quality of corporate governance (Aguilera \& Desender, 2012).

Conflict of Interest relationships within companies, arising from the separation of ownership and control, highlighting the agency relationship, characterized as a contract under which a (principal) person engages another person (agent) to provide some service that involves delegation of authority 
for agent decision-making (Jensen \& Meckling, 1976). Good governance therefore assures members of equity, transparency, accountability and compliance with the laws of the country. Corporate governance consists of a set of internal and external institutional and market mechanisms. Its main function is to guide decision-makers on how the company should be managed to maximize its value and, consequently, the benefits to the owners (Denis $\&$ McConnell, 2003). The mechanisms of corporate governance are ways of controlling agency conflicts in order to improve the asymmetries intrinsic to the functioning of the company (Andrade \& Rossetti, 2009).

Scattered capital firms seek to understand that the most common agency conflicts are of the principal-agent type, where there is greater emphasis on the role of the board in managing the monitoring. However, a controlling shareholder seeks to play a role in the board by monitoring management and reducing costs, since the controlling shareholder himself is interested in assuming that role (Aguilera \& Desender, 2012). Due to this, analysis of the structure of ownership and control of companies has become a subject of increasing discussion in capital markets, especially in countries where the concentration of actions among a few investors is evident, such as Brazil (Caixe \& Kraute, 2014).

The board of directors has the function of reducing agency problems, acting as an instrument of the internal control system of companies, with high participation of independent directors external to the company, separation of the functions of the general director of the company and the president of the board of directors, and a smaller number of members (Correia, Amaral, \& Louvet, 2014).

\section{BOARD INDEPENDENCE AND PERFORMANCE}

Studies on the independence and value of the company according to the board found meaning, noting that there is an ideal range, according to the size of the company, where the independence of the board is perceived by the market as a positive factor. Authors have also identified that companies with a similar profile in terms of composition of the board present different prices in their market depending on the size of the company or its performance, according to the indebtedness index (Andrade et al., 2009).

An effective board, according to the assumptions of agency theory, is characterized mainly by the high participation of external directors outside the firm and the separation of the functions of the CEO and the chairman of 
the board of directors. On the other hand, a poor quality board of directors is composed mainly of internal members or external directors linked to controllers and managers and chaired by the CEO (Chen et al., 2015). Accordingly, the great transformations that have occurred in the national economy-economic opening and privatization-have implied changes in shareholder identity, rather than concentration (Fontes Filho et al., 1998). Figure 3.1 summarizes the companies and the types of shareholder.

(Figure 3.1)

TYPE OF SHAREHOLDER

\begin{tabular}{lrrrrrrr}
\hline Shareholder & 2016 & 2015 & 2014 & 2013 & 2012 & 2011 & 2010 \\
\hline State-owned & $3.50 \%$ & $2.63 \%$ & $2.60 \%$ & $2.65 \%$ & $2.57 \%$ & $2.85 \%$ & $2.04 \%$ \\
\hline Foreign & $46.12 \%$ & $45.05 \%$ & $46.80 \%$ & $45.12 \%$ & $45.46 \%$ & $46.03 \%$ & $47.43 \%$ \\
\hline Family & $29.46 \%$ & $22.29 \%$ & $20.55 \%$ & $20.33 \%$ & $18.47 \%$ & $20.91 \%$ & $20.12 \%$ \\
\hline Institutional & $20.92 \%$ & $30.03 \%$ & $30.05 \%$ & $31.90 \%$ & $33.50 \%$ & $30.21 \%$ & $30.41 \%$ \\
\hline
\end{tabular}

Source: Elaborated by the authors.

In agreement with the empirical evidences reported by Silva (2004), despite the economic opening and the privatizations that took place in Brazil in the 1990s having significantly changed the identity of the controllers, ownership remains concentrated in the hands of family and foreign groups, being dominated by the three largest shareholders on average. Another relevant aspect of the ownership structure in Brazil of the highways operating companies is the degree of concentration (see Figure 3.2).

(Figure 3.2)

OWNERSHIP STRUCTURE OF COMPANIES

\begin{tabular}{lrrrrrrr}
\multicolumn{1}{c}{ Structure } & 2016 & 2015 & 2014 & 2013 & 2012 & 2011 & 2010 \\
\hline Concentrated & $75.26 \%$ & $73.05 \%$ & $75.23 \%$ & $78.75 \%$ & $80.03 \%$ & $76.20 \%$ & $64.12 \%$ \\
\hline Spread & $24.74 \%$ & $26.95 \%$ & $24.77 \%$ & $21.25 \%$ & $19.97 \%$ & $23.80 \%$ & $35.88 \%$ \\
\hline
\end{tabular}

Source: Elaborated by the authors.

Finally, highway concessionaires were a strategy of the Brazilian government to reduce the crisis of investment in infrastructure and an attractive route for the contribution of foreign investment and the interest 
in private capital, mainly in the participation in infrastructure projects, where there is dependence and greater stability in the macroeconomic sector.

The study by Epps and Ismail (2009) investigated the relationship between board of directors and performance, obtaining seven characteristics related to board and board of directors: 1 . board composition; 2 . board structure; 3 . board size; 4 . functions of the CEO; 5 . board disclosure policies; 6. existence and composition of an appointment committee; and 7. existence and composition of a compensation committee. Their research indicated that regulatory mechanisms of corporate governance, such as the board of directors, allowed a greater follow-up in the management process, besides being a relevant factor in the improvement of financial reports.

Rajpal (2012) primarily examined the impact of factors such as the presence of independent board members and the diligent behaviour and experience of independent advisors in relation to corporate performance in India, using a sample of 200 large companies listed on the Indian Stock Exchange for three financial years (2008/09, 2009/10 and 2010/11). The study did not find any significant relationship between board independence and performance, but found that companies that had very busy independent directors - that is, they held the position of chair of the board in other companies, or held other senior management positions-performed better, while companies with independent directors who did not hold the position of chairman in other companies performed significantly less well.

Thus, the board of directors is often considered the main internal control mechanism, responsible for management follow-up and for being the defender of the shareholders' interests (Chen et al., 2015). An effective board, according to the assumptions of agency theory, is characterized mainly by the high participation of independent directors outside the firm and the separation of the functions of CEO and the chairman. On the other hand, a low-quality board of directors is composed mainly of internal members, or external directors linked to controllers and managers, and chaired by the company's chief executive officer (Wu et al., 2016).

Moura, Almeida, Andreola, Vecchia, and Mazzioni (2017) sought to verify the influence of the independence of the board of directors on the management of results and the performance of public companies listed on the BM\&FBOVESPA in the period from 2012 to 2015 . The average proportion of independent members in the companies did not exceed 20 per cent. Regarding duality of president and president-in-chief, there was a considerable reduction in the period. It should be emphasized that this research contributed to strengthen the understanding of this little explored 
theme (independence of the board) in Brazil and expanded the discussion in the literature addressing factors influencing the performance and management of results.

Du et al. (2017) investigated the monitoring power that independent directors had to increase performance. The sample consisted of a group of Chinese publicly-traded companies with data available for the period from 2004 to 2012. The results showed that performance was negatively related to the presence and proportion of independent directors and that in state-owned enterprises performance was less obvious, compared to other types of company.

\section{CONFLICTS OF INTEREST AND THE BOARD OF DIRECTORS}

The board of directors is the central governance instrument. Through it, the shareholders, stakeholders, corporate market control and national and international regulations interact in a complex way to affect corporate actions and managerial monitoring (Monks \& Minow, 2001). Codes of good governance practice emphasizing the importance of a majority of the board of directors being composed of external members to increase the value of the company.

Furthermore, the board of directors is the main internal mechanism to reduce agency costs between shareholders and managers, and between controlling shareholders and minority shareholders (Silveira, 2002). This emphasizes the importance of the board of directors in the management and governance structure of organizations. In addition, Gondrige, Clemente, and Espejo (2012) argue that the board of directors is a market solution that helps alleviate the agency problems that afflict any large organization through codes or differentiated levels of governance, as it is also a legal regulatory system.

The IBGC (2012) classifies directors as independent, external or internal. Independent directors are those who have no ties with the company; external directors are those that do not have a current connection with the organization, but are not independent-for example, ex-directors, ex-employees, ex-consultants, among others; and internal directors are those who have a current relationship with the company (Cunha \& Martins, 2015). Figure 4.1 summarizes the types of directors. 


\section{(Figure 4.1)}

TYPES OF DIRECTORS AND COMPOSITION OF THE BOARD

\begin{tabular}{|c|c|c|}
\hline \multicolumn{2}{|c|}{ Type of Director } & \multirow[b]{2}{*}{ Characteristics } \\
\hline $\begin{array}{l}\text { CVM (2016) } \\
\text { IBGC (2012) }\end{array}$ & $\begin{array}{c}\text { ABRASCA } \\
(2011)\end{array}$ & \\
\hline Internal & Executive & Directors who are directors or employees of the company. \\
\hline External & $\begin{array}{c}\text { Non- } \\
\text {-executive }\end{array}$ & $\begin{array}{l}\text { Directors who have no current connection with the } \\
\text { organization, but are not independent-for example, former } \\
\text { directors and former employees, lawyers who provide services } \\
\text { to the company, etc. }\end{array}$ \\
\hline Independent & Independent & $\begin{array}{l}\text { The board of the organization should preferably have a } \\
\text { majority of independent directors. The independent board } \\
\text { member is characterized by not having any ties with the } \\
\text { organization, except a possible share of capital; not being a } \\
\text { controlling shareholder, member of the control group, spouse } \\
\text { or relative to the second degree of these; and not being linked } \\
\text { to organizations related to the controlling shareholder; }\end{array}$ \\
\hline
\end{tabular}

Source: Elaborated by the authors.

The boards of American companies with a majority of independent members behave differently from boards without this composition; some of these differences seem to contribute to an increase in the value of the companies, while other differences contribute to a decrease in value. The boards of directors are characterized by representing their companies in the definition of their strategies and the pursuit of their objectives in order to maximize revenue, acting in the roles of ratification and follow-up (Cunha $\&$ Martins, 2015). The role of the board has been a source of concern on the part of shareholders. Gondrige et al. (2012) reflect on the higher performance requirement, emphasizing monitoring of the management and improving risk control tools, not only for moments of crisis, but also in anticipation to avoid harmful consequences. In the works of the board, Fontes Filho et al. (2008) describe some classifications, summarized in Figure 4.2 below.

Through the board of directors, the shareholders, stakeholders, corporate market control and national and international regulations interact in a complex way to affect corporate actions and the monitoring of managers (Monks \& Minow, 2001). The importance of increasing the value of the company is down to the existence of a board of directors composed of a majority of independent members that stands out in the codes of good 
practice of corporate governance. This recommendation is supported by Jensen \& Meckling (1976), who argues that the inclusion of professional external directors increases the effectiveness of the board and reduces the possibility of collusion by senior executives in order to expropriate shareholder wealth. Classification of the board's roles is summarized in Figure 4.2.

\section{(Figure 4.2)}

\section{CLASSIFICATION OF THE ROLES OF THE BOARD OF DIRECTORS}

\begin{tabular}{ll}
\multicolumn{1}{c}{ Directors } & \multicolumn{1}{c}{ Key Features } \\
\hline Monitoring & $\begin{array}{l}\text { Faced with the context of damaged property, it seeks to monitor the actions } \\
\text { of the agent, aiming to align them with the interests of the principal. }\end{array}$ \\
\hline Strategy & $\begin{array}{l}\text { It acts in the strategic direction of the company, in which trust in the manager } \\
\text { replaces control. It acts to improve external relations, facilitating access to } \\
\text { resources and strengthening the legitimacy of the company. }\end{array}$ \\
\hline Relationships & $\begin{array}{l}\text { It acts to facilitate access to trading partners, and acts as an element of } \\
\text { interconnection with other companies in order to acquire specific resources, } \\
\text { skills and knowledge. }\end{array}$ \\
\hline Legitimacy & $\begin{array}{l}\text { It seeks to facilitate the acceptance of the company by society, through } \\
\text { credibility and help in the adequacy of the processes. }\end{array}$ \\
\hline Coordination of & $\begin{array}{l}\text { It trades by virtue of the convergence of interests between controlling and } \\
\text { interests }\end{array}$ \\
\hline Contingency shareholders, in an attempt to equalize their interests.
\end{tabular}

Source: Adapted from Fontes Filho (2012).

In Brazil, several studies have been carried out to analyse the structure and composition of boards of directors, including Leal and Oliveira (2002). These authors identified the profile of the boards of directors of 142 Brazilian companies in 1999, seeking to assess the degree of independence of the board of directors in relation to the controlling shareholders. For Silva (2004), an independent board assumes good governance practice, since it is responsible for evaluating the board and for replacing it, if that is in the interest of the shareholders.

Ararat, Orbay, and Yurtoglu (2010) studied the independence of the board of directors in controlled companies in Turkey, highlighting three main conclusions: 1 . there was no significant effect of the independence of 
the board of directors; 2. independent directors in Turkey were less efficient in containing related transactions; and 3. there was a negative relationship and no relationship between independent directors and performance.

The results of many of the previous studies suggest that more independent advisors contribute to more effective management while minimizing the performance of firms in various sectors of the economy. However, this is not a single conclusion, since research findings also show the null effect of hiring independent directors, especially when there are dual positions or influence of the controlling shareholder. Thus, a gap remains that this research intends to contribute to fill.

\section{EFFECT OF THE INDEPENDENCE OF THE BOARD OF DIRECTORS IN PERFORMANCE}

The board of directors is a body that has the responsibility to decide on behalf of the owners (IBGC, 2012). The attributes assumed by the board of directors are important factors that contribute to explain part of the performance and the market value of the companies (Silveira, 2002). The internal mechanism of the board of directors focuses on the management and monitoring of shareholders' interests. The composition and attributes of the advisors in organizations are factors that contribute to and explain the performance of companies (Aguilera \& Desender, 2012).

The relationship between the instruments of corporate governance and the value of the company has been demonstrated in other studies for Brazil, such as Silveira (2002). The point raised by this work, which differs from the previous ones, is to relate the governance mechanisms through the use of BM\&FBOVESPA's differentiated markets in the segment of road or sector concessions. This study seeks to assess to what extent adherence to these mechanisms, by ensuring better governance practices, produces a better assessment of the company in its market value.

Vieira et al. (2011) assess whether the adoption of corporate governance practices, especially through the board of directors, changes the capital structure and performance of companies. According to the results, as the board increased independence, there was lower variation in stock returns; also, in relation to the capital structure indicator, the results showed that board independence had a negative coefficient in relation to returns.

Gondrige et al. (2012) showed that the size of the board and the company's level of leverage are positively related, unlike duality and independence, which 
did not present any statistical significance. Board independence is an aspect that has an impact on performance, but in a negative way, since the presence of independent directors with poor knowledge about the business of the companies can affect the performance. Thus, the results indicated that the boards are largely dominated by representatives of the controlling shareholders and there is evidence of low utilization of voting mechanisms available to non-controlling shareholders. Combining the above arguments, we proceed with the methodological analyses.

\section{METHODOLOGICAL ASPECTS}

The main unit of analysis of this study is the boards of directors of companies listed on the São Paulo Stock Exchange (BM\&FBOVESPA) in the highway exploration segment from 2010 to 2016, as shown in the Figure below.

\section{(Figure 6.1)}

DIFFERENTIATED LEVELS OF HIGHWAYS EXPLORATION COMPANIES IN THE BM\&FBOVESPA

\begin{tabular}{lrrrrrrr}
\hline Companies & 2016 & 2015 & 2014 & 2013 & 2012 & 2011 & 2010 \\
\hline New market & $29.60 \%$ & $28.40 \%$ & $51.20 \%$ & $50.80 \%$ & $49.50 \%$ & $43.60 \%$ & $40.80 \%$ \\
\hline Level 2 & $51.20 \%$ & $52.80 \%$ & $31.40 \%$ & $22.40 \%$ & $16.40 \%$ & $14.20 \%$ & $7.40 \%$ \\
\hline Level 1 & $0.00 \%$ & $0.00 \%$ & $0.00 \%$ & $0.00 \%$ & $3.00 \%$ & $8.00 \%$ & $12.00 \%$ \\
\hline Traditional & $19.20 \%$ & $18.80 \%$ & $17.40 \%$ & $26.80 \%$ & $31.10 \%$ & $34.20 \%$ & $39.80 \%$ \\
\hline Total & $100.00 \%$ & $100.00 \%$ & $100.00 \%$ & $100.00 \%$ & $100.00 \%$ & $100.00 \%$ & $100.00 \%$ \\
\hline
\end{tabular}

Source: Elaborated by the authors.

These companies are more transparent and have their information audited, providing greater reliability in the information. This quantitative research is based on data and evidence collected, which can be quantified and measured. Regarding the means, the research is documentary, since it analyses the data on the valuation of actions composed by secondary data, made available by the organizations that operate in the Brazilian capital market. Regarding the quantitative data, which are secondary in nature, the collection of data regarding the ownership structure and the board of directors was carried out through the CVM (2016) electronic website. 
Economic-financial and market data were extracted from the Economatica ${ }^{\circledR}$ database, in dollarized values. The Stata ${ }^{\circledR} 13.0$ tool will be used as statistical support software. Figure 6.2 shows the data sources used.

\begin{tabular}{ll} 
& $($ Figure 6.2) \\
& SOURCES OF DATA \\
\hline \multicolumn{1}{c}{ Data source } & \multicolumn{1}{c}{ Definition } \\
\hline Economatica $^{\circledR}$ - BM\&FBOVESPA & Capturing economic-financial and market data \\
\hline CVM website $^{\text {Company website }}$ & Corporate governance variables \\
\hline
\end{tabular}

Source: Elaborated by the authors.

Between 2011 and 2015, the Federal Government with the National Transport Confederation plan (CNT) and the launch of the Logistics Investment Program (PIL) contributed to the development of a modern and efficient transportation system which will be implemented through strategic partnerships with the private sector. The first phase of the program had an estimated investment of $\mathrm{R} \$ 46$ billion; the second phase of the process of modernization of the country's transportation infrastructure was continuous, aimed at the resumption of economic growth and improvement of the conditions of the roads. It saw an investment of over $\mathrm{R} \$ 50.8$ billion in new concessions to be made during 2015 and 2016 and then another R\$15.3 billion in new investments in already active concessions (Ministry of Planning, Budget and Management, 2016). The highways were the first privatizations made by the federal government, in order to meet the state's constant need to raise funds for the expansion and maintenance of public services and transportation infrastructure (National Agency of Land Transport, 2016).

After data collection, a descriptive analysis of the main variables of interest to the research was carried out, followed by a regression analysis to verify the influence on performance of independence of the board of directors, and other control variables. With the purpose of analysing the influence of the board of directors on the performance of the highway exploration companies, the statistical method of fixed effects regression was used with panel data. The characteristics of panel data or longitudinal data present observations aligned over time in order to provide a better investigation of the dynamics of changes in the variables studied.

The theoretical framework presented serves as the basis for the choice of the variables investigated, according to previous studies that present 
similar objectives to this study. This choice made possible a comparison with the results obtained in previous studies. The variables were divided into three groups: dependent, independent and control. To test the influence and independence of the members of the board of directors of the listed highways, Figure 6.3 below shows the respective variables:

(Figure 6.3)

SUMMARY OF VARIABLES

\begin{tabular}{|c|c|c|c|c|}
\hline \multicolumn{2}{|r|}{ Variables } & \multicolumn{2}{|c|}{ Measurement } & Authors \\
\hline \multirow{2}{*}{ 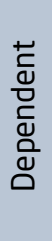 } & $\begin{array}{l}\text { Tobin's Q } \\
\text { (QTobin) }\end{array}$ & \multicolumn{2}{|c|}{$\begin{array}{l}\text { Represented by market value and the book value } \\
\text { of the company's current liabilities, divided by the } \\
\text { carrying amount of the company's current assets }\end{array}$} & Peixoto (2012); \\
\hline & $\begin{array}{l}\text { Market-to-book } \\
\text { ratio (MBook) }\end{array}$ & \multicolumn{2}{|c|}{$\begin{array}{l}\text { Expresses the market value based on the shares, } \\
\text { divided by the value of the total assets }\end{array}$} & $\begin{array}{l}\text { Andrade et al. } \\
\text { (2009); }\end{array}$ \\
\hline \multirow{3}{*}{ 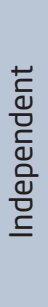 } & \multirow[t]{3}{*}{$\begin{array}{l}\text { Administrative } \\
\text { board }\end{array}$} & $\begin{array}{l}\text { Proportion of } \\
\text { independents (IND) }\end{array}$ & Number of members & Peixoto (2012) \\
\hline & & Duality (DUO) & Binary (CEO=1, D=0) & $\begin{array}{l}\text { Du et al. (2017); } \\
\text { Rajpal (2012) }\end{array}$ \\
\hline & & Size of board (TC) & Given by total membership & $\begin{array}{l}\text { Silveira (2002); } \\
\text { Peixoto (2012) }\end{array}$ \\
\hline 온 & \multicolumn{2}{|c|}{$\begin{array}{l}\text { Profitability on shareholders' equity } \\
\text { (ROE) }\end{array}$} & $\begin{array}{l}\text { Measured by dividing net } \\
\text { income by average equity } \\
\text { of companies }\end{array}$ & $\begin{array}{l}\text { Silveira (2002); } \\
\text { Peixoto (2012) }\end{array}$ \\
\hline ت & \multicolumn{2}{|c|}{ Company size (TE) } & Logarithm of total assets & $\begin{array}{l}\text { Habbash et al. } \\
(2014)\end{array}$ \\
\hline
\end{tabular}

Source: Elaborated by the authors.

Based on agency theory, we also control some ownership variables that have implications for firms' strategy. The first variable is the percentage of voting shares owned by the largest shareholder. The objective is to control the level of concentration of the ownership. Thus, shareholder identity is measured through four binary variables that receive the value of 1 if the most relevant shareholder is family, institutional investor, foreign or government. Private companies are the reference. A description of the variables is presented in Figure 6.3.

The analysis method was the regression of fixed effects with panel data. The equation that represents the general model of the regression is: 
Independence board it $=\beta 0+\beta 1 X 1$ it $+\beta 2 X 2 i t+\ldots+\beta n X n i t+\alpha i+\varepsilon i t$

where performance is the level of influence of the board administration measured by indicators of the performance (ROE, TE); it is company $\mathrm{i}$ in period $\mathrm{t} ; \beta \mathrm{o}$ is the intercept; $\beta 1 \mathrm{X} 1$ it represents each independent variable (from Model 1 to Model 2); $\beta$ Xnit represents all the control vectors; $a i$ varies from one company to another and is constant over time, capturing differences in behaviour between firms; and cit expresses the error variation observed in relation to that expected. Robust coefficients were used to improve the consistency of the results and ensure the robustness of the proposed model because of the possibility of heteroscedastic data.

The descriptive verification of the variables began with the mean of the variables and the standard deviation. Through the mean, it was verified that there was a great discrepancy between the minimum value and the maximum value of the variables. Thus, the DFBeta technique was used to verify the existence of atypical observations (outliers). Subsequently, the univariate normality of all dependent, independent and control variables was verified. When the normality test was applied, and skewness and kurtosis were checked, however, all results were significant, so the null hypothesis that the data were normal was rejected. Figure 6.4 shows the indicators of the descriptive statistics of the variables of the sample companies, referring to the period from 2010 to 2016 .

\section{(Figure 6.4)}

RESULTS OF THE DESCRIPTIVE STATISTICS OF THE VARIABLES

\begin{tabular}{|c|c|c|c|c|c|c|}
\hline Variables & Mean & SD & Min & Max & Asymmetry & Kurtosis \\
\hline Tobin's Q & 7.33 & 0.92 & 3.02 & 9.38 & 0.00 & 0.00 \\
\hline Market-to-book & 5.29 & 2.37 & 0.92 & 10.4 & 0.49 & 0.00 \\
\hline Proportion of independents & 1.22 & 1.08 & 0 & 3 & 0.19 & 0.00 \\
\hline Duality & 0.44 & 0.49 & 0 & 1 & 0.20 & 0.00 \\
\hline Size of board & 7.01 & 2.47 & 2 & 11 & 0.23 & 0.01 \\
\hline $\begin{array}{l}\text { Profitability on shareholders' } \\
\text { equity }\end{array}$ & 26.99 & 34.92 & -11.4 & 123.3 & 0.01 & 0.00 \\
\hline Company size & 122.3 & 349.04 & 126.3 & 161.2 & 0.00 & 0.00 \\
\hline
\end{tabular}


After presenting the correlation matrix, we test the research model from the equation, which contains the indicators for the data analysis in the fixed effects panel. The fixed effects model can be estimated with the Stata tool by the "xtreg" option. Stata ${ }^{\circledR}$ vce (robust) routines were used to control the multicollinearity of the variable residues.

\section{PRESENTATION AND DISCUSSION OF RESULTS}

This section contains the description and analysis of the data. Firstly, the descriptive statistics of the performance indicators are presented. Figure 7.1 shows the performance indicators (variables ROE and TE) of the sample companies for the period 2010 to 2016.

When analysing the performance indicators (Figure 7.1), it can be seen that, in 2010, the highest level of competence adjustment was to increase the results, since 63 per cent $(20 \%+43 \%)$ of the 19 companies had positive indicators - that is, higher than 0 . It should be noted that among companies that performed to increase the result (63\%), 43 per cent of the competency adjustments occurred in greater proportions $(>0.010)$.

(Figure 7.1)

DESCRIPTIVE STATISTICS OF PERFORMANCE INDICATORS

\begin{tabular}{cccc}
\hline \multirow{2}{*}{ Variables } & \multirow{2}{*}{ Indicators } & \multicolumn{2}{c}{ Number of Companies } \\
\cline { 3 - 4 } & & Number & Percentage \\
\cline { 2 - 4 } & $>-0.10$ & 9 & $30 \%$ \\
\cline { 2 - 4 } 2010 & $-0.10-0.00$ & 5 & $17 \%$ \\
\cline { 2 - 4 } & $0.01-0.10$ & 6 & $20 \%$ \\
\cline { 2 - 4 } & $>0.10$ & 13 & $43 \%$ \\
\hline \multirow{3}{*}{2011} & $>-0.10$ & 3 & $10 \%$ \\
\cline { 2 - 4 } & $-0.10-0.00$ & 7 & $23 \%$ \\
\cline { 2 - 4 } & $0.01-0.10$ & 14 & $36 \%$ \\
\hline
\end{tabular}


(Figure 7.1 (conclusion))

DESCRIPTIVE STATISTICS OF PERFORMANCE INDICATORS

\begin{tabular}{|c|c|c|c|}
\hline \multirow{2}{*}{ Variables } & \multirow{2}{*}{ Indicators } & \multicolumn{2}{|c|}{ Number of Companies } \\
\hline & & Number & Percentage \\
\hline \multirow{4}{*}{2012} & $>-0.10$ & 4 & $13 \%$ \\
\hline & $-0.10-0.00$ & 2 & $7 \%$ \\
\hline & $0.01-0.10$ & 16 & $53 \%$ \\
\hline & $>0.10$ & 11 & $36 \%$ \\
\hline \multirow{4}{*}{2013} & $>-0.10$ & 2 & $7 \%$ \\
\hline & $-0.10-0.00$ & 6 & $20 \%$ \\
\hline & $0.01-0.10$ & 7 & $23 \%$ \\
\hline & $>0.10$ & 18 & $59 \%$ \\
\hline \multirow{4}{*}{2014} & $>-0.10$ & 4 & $13 \%$ \\
\hline & $-0.10-0.00$ & 6 & $20 \%$ \\
\hline & $0.01-0.10$ & 13 & $43 \%$ \\
\hline & $>0.10$ & 10 & $33 \%$ \\
\hline \multirow{4}{*}{2015} & $>-0.10$ & 6 & $20 \%$ \\
\hline & $-0.10-0.00$ & 8 & $26 \%$ \\
\hline & $0.01-0.10$ & 10 & $33 \%$ \\
\hline & $>0.10$ & 9 & $29 \%$ \\
\hline \multirow{4}{*}{2016} & $>-0.10$ & 3 & $9 \%$ \\
\hline & $-0.10-0.00$ & 4 & $13 \%$ \\
\hline & $0.01-0.10$ & 12 & $39 \%$ \\
\hline & $>0.10$ & 14 & $46 \%$ \\
\hline
\end{tabular}

Source: Elaborated by the authors.

In relation to 2011 and 2012, it can be observed in Figure 7.1 that the number of companies that performed the highest proportions with positive indicators increased from 63 percent in 2010 to 76 per cent 2011 and 89 per 
cent in 2012. It is also noted that in the 46 per cent of the 277 companies with positive indicators calculated in 2011, competency adjustments occurred to increase accounting results, and in 53 per cent of cases in 2012, performance increased the results.

In the years 2013 and 2014, the number of companies that performed to increase results remained close to 55 per cent, while the number of companies that had performance which decreased results remained close to 33 per cent, below that occurring in the year 2012. In relation to the year 2015, the biggest change occurred in the number of companies that performed poorly ( 0.00 to 0.10 ), which was reduced to 10 (that is, $33 \%$ ) from 46 per cent in 2011. Following are the average percentages of independent board members, the totals of companies in which the majority of the board members are independent and the totals of companies in which there is duality of position of chairman of the board of directors and chief executive officer. Finally, the results of the multiple linear regression are presented, which allows us to arrive at the objective of this study.

Figure 7.2 presents the average percentages of independent members on the boards of directors of companies listed on BM\&FBOVESPA from 2010 to 2016. It should be noted that the percentages of independent members were considered in relation to the size of the board of directors, in a similar way to the studies of Habbash et al. (2014) and Chen et al. (2015).

\section{(Figure 7.2)}

RESULTS OF TYPES OF MEMBERS OF THE BOARD OF DIRECTORS

\begin{tabular}{lrrrrrrr}
\hline \multicolumn{1}{c}{ Directors } & 2016 & 2015 & 2014 & 2013 & 2012 & 2011 & 2010 \\
\hline Internal & $40.54 \%$ & $39.40 \%$ & $40.22 \%$ & $43.25 \%$ & $47.57 \%$ & $45.56 \%$ & $50.84 \%$ \\
\hline External & $32.03 \%$ & $33.25 \%$ & $30.54 \%$ & $30.10 \%$ & $20.13 \%$ & $22.89 \%$ & $20.70 \%$ \\
\hline Duality (CEO-Director) & $1.87 \%$ & $2.92 \%$ & $3.45 \%$ & $3.80 \%$ & $8.85 \%$ & $11.53 \%$ & $11.25 \%$ \\
\hline Independent & $25.56 \%$ & $24.43 \%$ & $25.79 \%$ & $22.85 \%$ & $23.45 \%$ & $20.02 \%$ & $17.21 \%$ \\
\hline
\end{tabular}

Source: Elaborated by the authors.

It can be seen from Figure 7.2 above that the percentage of companies in which there was a duality in the positions of president of the board and CEO decreased in the period from 2013 to 2016, which indicates an improvement in this aspect, since the separation of positions guarantees that the CEO will not have excessive power over the board, as emphasized by Siam et al. (2014). 
In 2010, the same person held the functions of chairman of the board of directors and the position of chief executive officer of the company in 11.25 per cent of cases, and in 2011, in 11.53 per cent of companies. This percentage fell to 8.85 per cent in 2012 , to 3.80 per cent in 2013 , to 3.45 per cent in 2014, to 2.92 per cent in 2015 and to 1.87 per cent in 2016.

Regarding the average percentages of independent members on the boards of directors of companies listed on the BM\&FBOVESPA in the period 2012-2015, the average percentages identified are lower than those identified in previous surveys such as Rajpal (2012), who identified an average percentage of independence corresponding to 53 per cent in Indian companies; Alves (2014), who analysed Portuguese companies and found an average perc of 30 per cent; Habbash et al. (2014), who identified an average of 33 per cent in Chinese companies; and Chen et al. (2015), who studied companies in Singapore and found an average of 75 per cent.

It is important to emphasize that the difference in results may be due to sample formation criteria. However, the percentages in this research point to a low ability of the board to monitor managers, since its independence from the controller and management itself appears to be compromised. As for the totals of companies in which the majority of the board members are independent, again the average percentages are lower than those identified in previous studies, such as Rajpal (2012), where 50 per cent of the Indian companies in the sample had a board of directors consisting of a majority of independent members, and that of Chen et al. (2015), in which approximately 90 per cent of the companies listed on the Singapore Stock Exchange held a board of directors composed of a majority of independent members.

Figure 7.3 shows the regression coefficients, which make it possible to verify the influence of the board's independence on performance. However, before starting the analysis, it should be highlighted that the performance indicators can be both positive and negative. Thus, although in a given company the indicator is negative (equivalent to -0.05 , for example), it does not mean that, in proportional terms, the performance was lower than that of a company that presented a positive indicator of 0.05 . The difference is that while one performed to reduce the result, the other performed to increase the result. 


\section{(Figure 7.3)}

RESULTS OF MODELS WITH BOARD OF DIRECTORS

\begin{tabular}{|c|c|c|}
\hline \multirow{2}{*}{ Variables } & Model 1 & Model 2 \\
\hline & QTobin & MBook \\
\hline Size of board & -0.506 & -0.410 \\
\hline Duality & -1.116 & -0.962 \\
\hline Proportion of independents & 0.090 & 0.077 \\
\hline Profitability on shareholders' equity & 0.113 & 0.107 \\
\hline Company size & 0.0615 & 0.0567 \\
\hline _cons & 4.755 & 2.687 \\
\hline sigma_u & 2.589 & 2.798 \\
\hline sigma_e & 1.869 & 2.075 \\
\hline Rho & 0.657 & 0.645 \\
\hline Obs & 180 & 180 \\
\hline$p<0.10 ; p<0.05 ; p<0.01$ & & \\
\hline
\end{tabular}

Source: Elaborated by the authors.

The figure shows the three variables related to the independence of the board of directors. The variable that captures the number of independent directors (IND) presented a positive coefficient of 0.07 and 0.09 , which is not statistically significant, verified if the size of the board (TC) and the position of director-president and chairman of the board of directors is occupied by the same individual (DUO). Regarding the control variables in relation to the dependent variables, we verified that all were statistically significant. The performance variables presented positive coefficients of $0.06,0.05,0.10$ and 0.11 , respectively.

\section{FINAL CONSIDERATIONS}

The objective of this research was to analyse the independence of the board of directors as a shareholder and then to understand the composition of the board of directors of private highways companies listed on the 
BM\&FBOVESPA between 2010 and 2016. Below, Figure 8.1 presents the main results of the quantitative analysis in relation to the theoretical findings.

\section{(Figure 8.1)}

\section{MAIN RESULTS OF THE QUANTITATIVE ANALYSIS AND THEORETICAL RESULTS}

\begin{tabular}{llc}
\multicolumn{1}{c}{ Hypothesis } & \multicolumn{1}{c}{ Authors corroborating } & Results \\
\hline HI: The influence of & Regarding performance, the result is similar to & \\
independent members & that of Habbash et al. (2014), who identified a & HYPOTHESIS \\
$\begin{array}{l}\text { on boards of directors } \\
\text { positively affects }\end{array}$ & $\begin{array}{l}\text { positive association between performance and } \\
\text { independence of the board, aiming at obtaining } \\
\text { corporate performance }\end{array}$ & ACCEPTED \\
\hline
\end{tabular}

Source: Elaborated by the authors.

We find a significant relationship between the independence of the board of directors and the performance of firms, albeit the opposite direction of the hypothesis, suggesting that the companies with the largest number of independent members on the board have, on average, higher performance. These results are associated with some indeterminacy in the literature on the effect of the independence of boards of directors on company performance.

One of the strong indicators of this research was to prove that the participation of a greater number of independent directors positively affected the market value and contributed more to the reduction of the conflict between the shareholder and the agency executives. The quality of corporate governance among companies is linked to investor control policies through its legal rules and to external investors in its publicly traded companies, but the authors assert that the gap that interferes with the legal system is the attempt to or form of evaluation of the public of companies around the world through the ownership structure (Bebchuk \& Hamdani, 2009).

In addition to the research on the independence of the board of directors, size (Shah et al., 2009) and growth (Du et al., 2017) were used as control variables. For future research, it is suggested the performance sector to be investigated, as by Habbash et al. (2014), which offers conflicting results. It is also suggested the moderating effect of stock concentration in the relationship between board independence and performance to be verified, as in the study by Wu et al. (2016), as well as the occurrence of several factors such as audit by big four, investigated by Alves (2014) and Du et al. (2017), and institutional property, studied by Chen et al. (2015). 
It should be emphasized that this research contributes to strengthen the understanding of this issue in the Brazilian case and expands the discussion in the literature when addressing the influence of independence of the board on performance, which is still little explored in Brazil. It also adds to literature in the area with empirical evidence regarding the Brazilian case, which lacks research of this nature. Despite its scientific rigour and methodological care, the research has limitations, including the fact that the sample is made up of companies listed on the BM\&FBOVESPA, so that the results cannot be generalized to other organizations, being restricted to those that composed the research sample. To solve this limiting factor, it is recommended to increase the number of companies studied, including the selection of private companies.

However, despite the limitations of this work, the subject searched is relevant and does not invalidate the results obtained, which may contribute to the literature and serve as a reference for later studies.

\section{CONSELHO DE ADMINISTRAÇÃO: A PERSPECTIVA DOS INDEPENDENTES NO DESEMPENHO DAS ORGANIZAC̄ÕES PRIVADAS? EVIDÊNCIAS NO BRASIL}

\section{RESUMO}

Objetivo: O estudo busca verificar a influência da independência do conselho de administração no desempenho das empresas listadas na BM\&FBOVESPA e analisar quais conflitos de agência influenciam o desempenho do conselho de administração.

Originalidade/relevância: O fato de o Brasil ser um país emergente que não possui um sistema legal rígido e fatores de controle da corrupção nesses ambientes e o setor público enfatiza a importância de aplicar o melhor código de práticas de governança corporativa nos principais países desenvolvidos, refletindo a necessidade para órgãos de supervisão eficazes que contribuam para um melhor desempenho financeiro das empresas.

Principais aspectos metodológicos: O estudo envolveu uma pesquisa quantitativa utilizando uma amostra de 33 empresas no segmento concessão de rodovias e 220 relatórios de 2010 a 2016 . Um modelo de regressão de efeitos fixos com dados em painel foi usado para análise. 
Síntese dos principais resultados: Os resultados foram estatisticamente significativos para as variáveis de independência do conselho, o que confirma a teoria de que a presença de independentes como membros do conselho influencia positivamente a gestão financeira e a empresa que detém o membro executivo e presidente do conselho tem um efeito negativo. O tamanho do conselho não apresentou significância estatística.

\section{PALAVRAS-CHAVE}

Teoria da agência. Governança corporativa. Conselho de administração. Consultor independente. Desempenho.

\section{REFERENCES}

Brazilian Association of Publicly-Held Companies. (2011). Abrasca code of self-regulation and best practices of publicly held companies. Retrieved from www.abrasca.org.br

Adi, T., Handayani, W., \& Rahayu, S. (2013). The influence of corporate governance and capital structure on risk, financial performance and firm value: A study on the mining company listed in Indonesia Stock Exchange in 2009-2012. European Journal of Business and Management, 5(29), 200-217.

Aguilera, R. V., \& Desender, K. (2012). Methodological challenges in comparative corporate governance and strategic issues. In C. L. Wang, D. Ketchen, \& D. Bergh (Eds.), Research methodology in strategy and management. Bingley (UK): Emerald Group Publishing Limited.

Alves, S. (2014). The effect of board independence on the earnings quality: Evidence from Portuguese listed companies. Australasian Accounting Business E Finance Journal, 8(3), 23-44.

Andrade, A., \& Rossetti, J. P. (2009). Corporate governance: An analysis of the board's relationship with the market value and performance of Brazilian companies. Journal of Management Mackenzie, 10(4), 4-31.

Ararat, M., Orbay, H., \& Yurtoglu, B. B. (2010). The effects of board independence in controlled firms: Evidence from Turkey. Manuscript in preparation. 
Bebchuk, L., \& Hamdani, A. (2009). The elusive quest for global governance standards. University of Pennsylvania Law Review, 28(3), 263-1317.

Bittencourt, M. V. C. (2006). Control of public service concessions. Belo Horizonte (BH): Forum.

Brazil. (2016, May). Vice-Presidency of the Republic. Provisional Measure No. 727 of May 12. Creates the Investment Partnerships Program (PPI) and provides other measures. Official Gazette.

Brazilian Institute of Corporate Governance. (2012). Code of best corporate governance practices. São Paulo (SP): Brazilian Institute of Corporate Governance.

Caixe, D. F., \& Krauter, E. (2014). The relationship between corporate governance and market value: Mitigating endogeneity problems. Brazilian Business Review, 11(1), 90-110.

Chen, X., Cheng, Q., \& Wang, X. (2015). Does increased board independence reduce earnings management? Evidence from recent regulatory reforms. Review of Accounting Studies, 20(2), 899-933.

Correia, L. F., Amaral, H. F., \& Louvet, P. (2014). Determinants of the efficiency of boards of directors of companies traded at BM\&FBOVESPA. Journal of Accounting and Organizations, 26, 45-57.

Cunha, A. S. L., \& Martins, O. S. (2015). Reflection of the characteristics of the board of directors in the indebtedness of publicly traded companies in Brazil. Corporate Governance Review, 2(1), 37-65.

Denis, D. K., \& McConnell, J. J. (2003). International corporate governance. The Journal of Financial and Quantitative Analysis, 38(1), 1-36.

Du, X., Jian, W., \& Lai, S. (2017). Do foreign directors mitigate earnings management? Evidence from China. The International Journal of Accounting, 52(1), 142-177.

Epps, R. W., \& Ismail, T. H. (2009). Board of directors' governance challenges and earnings management. Journal of Accounting \& Organizational Change, 5(3), 390-416.

Fontes Filho, J. R., \& Picolin, L. M. (2008). Corporate governance in state enterprises: Advances, proposals and limitations. Journal of Public Administration, $42(6), 1163-1168$.

Gondrige, E. O., Clemente, A., \& Espejo, M. M. S. B. Structure of the Board of Directors and value of Brazilian companies. Brazilian Business Review, 9(3), 72-95, 2012. 
Guasch, J. L. (2004). Granting and renegotiating concessions: Doing it right. Washington (DC): The World Bank.

Habbash, M., Xiao, L., Salama, A., \& Dixon, R. (2014). Are independent directors and supervisory directors effective in constraining earnings management? Journal of Finance, Accounting and Management, 5(1), 125-160.

Jensen, M. C. (2001). Theory of the firm: Governance, residual claims, and organizational forms. Cambrigde (MA): Harvard University Press.

Jensen, M. C., \& Meckling, W. H. (1976). Theory of the firm: Managerial behavior, agency costs and ownership structure. Journal of Financial Economics, 3(4), 305-360.

Koerniadi, H., Krishnamurti, C., \& Tourani-Rad, A. (2014). Corporate governance and risk-taking in New Zealand. Australian Journal of Management, 39(2), 227-245.

Leal, R., \& Oliveira, C. (2002). An evaluation of board practices in Brazil. Corporate Governance, 2.

Ministry of Planning, Budget and Management. (2016). PPA 2015. Retrieved from www.logisticabrasil.gov.br/index.php/content/view/2780.html

Monks, R. A. G., \& Minow, N. (2001). Corporate governance ( $2^{\text {nd }}$ ed). Cambridge (MA): Blackwell Business.

Moura, G. D., Almeida, I. X., Andreola, L., Vecchia, D., \& Mazzioni, S. (2017). Influence of the independence of the board of directors in results management. Accounting, Management and Governance, 20(3), 370-391.

National Agency of Land Transport. (2016). Infrastructure Exploration Superintendence (SUINF). Concessions of Federal Highways. Annual Report 2010-2015, Brasília.

OECD. (2011). Organization for human development and cooperation. OECD guidelines for multinational enterprises (pp. 1-72). São Paulo (SP): OECD.

Peixoto, F. M. (2012). Corporate governance, performance, value and risk: A study of changes in times of crisis (Doctoral dissertation). Retrieved from \#http:// www.bibliotecadigital.ufmg.br/dspace/handle/1843/BUBD-92MJUW

Piccoli, P. G. R., Souza, A., \& Silva, W. V. (2014). Do corporate governance practices slow down results management? Evidence from the aversion to disclosing losses and falling profits. Revista Contemporânea de Contabilidade, 11 (22), 141-162.

Posner, R. A. (2007). Theories of economic regulation. The Bell Journal of Economics and Management Science, 5(2), 335-358. 
Rajpal, H. (2012). Independent directors and earnings management: Evidence from India. International Journal of Accounting and Financial Management Research, 2(4), 2249-6882.

Shah, S. Z. A., Zafar, N., \& Durrani, T. K. (2009). Board composition and earnings management: An empirical evidence from Pakistani listed companies. Middle Eastern Finance and Economics, 3(29), 28-38.

Siam, Y. I. S. A., Laili, N. H. B., \& Khairi, K. F. B. (2014). Board of directors and earnings management among Jordanian listed companies: Proposing conceptual framework. International Journal of Technical Research and Applications, 2(3), 1-7.

Silva, A. L. C. da. (2004). Governança corporativa, valor, alavancagem e política de dividendos das empresas brasileiras. Revista de Administração, 39(4), 348-361.

Silveira, A. D. M. (2002). Corporate governance, performance and value of the company in Brazil(Master's thesis). Retrieved from http://www.teses.usp. br/teses/disponiveis/12/12139/tde-04122002-102056/en.php

Vieira, K. M., Velasquez, M. D., Losekann, V. L., \& Cereta, P. S. (2011). The influence of corporate governance on the performance and structure of the companies listed on Bovespa. Revista Universo Contábil, 7 (1), 49-67.

Wu, S., Chen, C. M., \& Lee, P. C. (2016). Independent directors and earnings management: The moderating effects of controlling shareholders and the divergence of cash-flow and control rights. The North American Journal of Economics and Finance, 35, 153-165.

\section{AUTHOR NOTE}

Ruan C. dos Santos, Universidade do Vale do Itajaí (Univali); Lidinei É. Orso, Univali. Suzete A. Lizote, Univali. Rosilene Marcon, Universidade Federal de Santa Catarina (UFSC).

Ruan C. dos Santos is now Professor Assistant at Centro Universitário Leonardo Da Vinci (Uniasselvi). Lidinei É. Orso is now Professor at Faculdade Borges de Mendonça (FBM), campus of Biguaçu. Suzete A. Lizote is now Professor of Business at Univali; Rosilene Marcon is now Program Coordinator and Professor at Postgraduate Program in Administration at Univali.

Correspondence concerning this paper should be addressed to Ruan C. dos Santos, Rua Pedro Eulálio Andriani 220, Centro, Tijucas, Santa Catarina, Brazil, CEP 88200-000.

E-mail: ruan_santos1984@hotmail.com 
Ruan C. dos Santos, Lidinei É. Orso, Suzete A. Lizote, Suzete A. Lizote, Rosilene Marcon

\section{EDITORIAL BOARD}

Editor-in-chief

Silvio Popadiuk

Associated Editor

Paulo Ceretta

Technical Support

Vitória Batista Santos Silva

\section{EDITORIAL PRODUCTION}

Publishing Coordination

Irina Migliari

Language Editor

Daniel Leão

Editorial Trainee

Maria Luiza Vanz

Layout Designer

Emap

Copyeditor

Irina Migliari
Graphic Designer

Libro 